Original Research

\title{
Improving Students' Higher Environmental and Climate Change Knowledge: A Case Study
}

\author{
Jelena Andreja Radaković, Nataša Petrović*, Nemanja Milenković, \\ Kristina Stanojević, Aleksandar Đoković
}

University of Belgrade, Faculty of Organizational Sciences, Jove Ilića 154, Belgrade, Serbia

Received: 8 February 2017

Accepted: 19 March 2017

\begin{abstract}
Having in mind that the growing body of research and case studies have predefined environmental education and its objectives in non-traditional education that rely on relevant modern teaching models such as project-based learning, this paper will focus on the scientific research of organized academic environmental activities in a climate-change oriented project in order to achieve learning objectives of higher environmental and climate change knowledge of students. This is particularly important considering the importance of climate change issues as the integral part of the present day student body, as well as a part of their social and personal lives. For the purpose of our research we surveyed the students of the University of Belgrade - Faculty of Organizational Science, the Republic of Serbia, who participated in this project not only regarding their attitudes referred to gaining environmental and climate change knowledge in this particular way, but also on their achievement levels in faculty environmental studies program. An analysis of the results was carried out using the SPSS 24 software package. Based on the obtained results we concluded that students were significantly motivated to improve their environmental and climate change knowledge, as well as that they showed greater motivation and willingness to participate again in similar environmental activities.
\end{abstract}

Keywords: environmental education, higher environmental education, climate change knowledge, climate change-oriented project

\section{Introduction}

Environmental problems [1-3] reached their critical point in the $21^{\text {st }}$ century and continue to grow rapidly: global warming, the deterioration of living conditions, disruption of the ozone layer, the impacts of conservation,

*e-mail: petrovicn@fon.bg.ac.rs increases in the amount of solid waste, radioactive contamination, destruction of forests, the extinction of plant and animal species, etc. [4]. In parallel, an increase in the global population has led to an increase in inefficient consumption of natural resources [5]. In Stockholm in 1972 the first United Nations Conference on the Human Environment was held, which was a turning point in humanity's relationship with the environment, bearing in mind that for the first time, environmental problems became the most important topic of a global agenda [6]. 
It is evident that the environmental crisis is getting worse and that, consequently, the concept of sustainable development has received its deserved attention in recent decades. When it comes to conditions for a successful transition to a sustainable development model we should emphasize the quality of human resources in which environmental education plays a key role because it is aimed at training to create social changes that lead to the creation of sustainable societies. Thus this kind of education is the most important part for a sustainable future [7].

The importance of environmental education was recognized in the 1970s, when the Stockholm Declaration was "formalized" [8] and its international foundations were laid in two documents: the Belgrade Charter and Tbilisi Declaration [9-10]. It must be noted that knowledge itself is not enough for a responsible attitude toward the environment [11-12], and that environmental education should have the following outcomes: a deep understanding of the environment plus confidence, skills, and opportunities to actively participate in solving environmental problems.

Global warming or climate change is the biggest environmental problem facing humanity and the most serious challenge for present and future generations because it is reshaping our understanding of progress and scientific and technological development. The seriousness of the issue is reflected in the fact that the United Nations has recognized "the link between climate change and human rights as an important step toward protecting the fundamental rights of communities across the planet" [13]. These are the reasons why it is considered that education must be "an essential element of the global response to climate change" [14]. Such education should be "encouraging innovative teaching approaches to integrate climate change education ... as well as enhancing non-formal education programmes" [14].

In light of the above - as well as the fact that "academia has a key role in the field of accumulating, deepening, and transferring knowledge of the environment through the processes of scientific research and education of large numbers of students" [15] - the authors of this paper chose to do their research relevant to the students' assessment of statements set out in the questionnaire relating to their participation in the project of promoting practical students' knowledge on climate change at the Belgrade Science Festival, and consequently the improvement of their accomplishments in this specific environmental science field. The aim of the project was to provide education to the students with appropriate environmental knowledge, attitudes, and values [16]. The study included all 45 students $(100 \%)$ enrolled at the elective course Design for Environment at the University of Belgrade as offered by the Faculty of Organizational Sciences, who participated in the project. An analysis of the results was carried out using the SPSS 24 software package. Our research sought to answer what students think about three main research questions:
1. Is a method of learning that involves participation in a project of an interactive exhibit at the science festival more interesting than the classic method of studying?

2. Does this method result in higher motivation for learning and gaining knowledge?

3. After participation in this project are students more motivated to change their environmental behavior?

\section{Literature Review}

The Belgrade charter talks about a new approach to social development that emphasizes the protection and improvement of the environment, which is only possible with reform of the education system, because "environmental education is the most important element of common response to the environmental crisis" [9]. According to the charter, the goal of environmental education is to influence the development of the world population that is aware of and concerned about the environment and problems related to it, and which has the knowledge, skills, attitudes, motivation, and obligation to individually and collectively work to resolve the current problems and the prevention of new [9].

The Tbilisi declaration adopted in 1977 provides a detailed description of the objectives of environmental education. It talks about the need to foster awareness and concern about the economic, social, political, and environmental interdependence in urban and rural areas, providing a chance for everyone to acquire knowledge, skills, and abilities necessary to work on the preservation and improvement of the environment, and creating new patterns of behavior of individuals, groups, and society as a whole.

The universal goals of environmental education accept [10]:

1. Awareness - help community groups and individuals in gaining awareness and sensitivity toward the environment and the problems associated with it.

2. Knowledge - help community groups and individuals acquire varied experience and a basic understanding of the environment and problems related to it.

3. Attitudes - help community groups and individuals adopt a set of values and a sense of interest in the environment and problems related to it.

4. Skills - help social groups and individuals acquire the skills for identifying and solving environmental problems.

5. Participation - to provide opportunities for community groups and individuals to actively participate in solving environmental problems at all levels of work.

When it comes to higher environmental education it must be noted that this form of education is learnercentered, providing learners with opportunities to construct their own understandings through hands-on, minds-on investigations and direct experiences in using higher-order thinking skills [17-19]. These characteristics of higher environmental education have allowed environmental educators to develop programs that lead to the formation 
Table 1. Objectives and aims of higher environmental education [20].

\begin{tabular}{|c|c|c|c|}
\hline \multicolumn{3}{|c|}{ Objectives of higher environmental education } & \multirow{2}{*}{$\begin{array}{l}\text { Aims of higher environmental } \\
\text { education }\end{array}$} \\
\hline Knowledge & Skills & Values & \\
\hline $\begin{array}{l}\text { The resources of the Earth, } \\
\text { particularly soil, water, } \\
\text { minerals, etc, and their } \\
\text { distribution and role in } \\
\text { supporting living organisms. } \\
\text { The implications of resource } \\
\text { distribution in determining } \\
\text { the nature of societies and } \\
\text { the rate and character of } \\
\text { economic development. } \\
\text { The role of science } \\
\text { and technology in the } \\
\text { development of societies } \\
\text { and the impact of these } \\
\text { technologies on the } \\
\text { environment. } \\
\text { Cooperative international } \\
\text { and national efforts to find } \\
\text { solutions to common global } \\
\text { issues, and to implement } \\
\text { strategies for a more } \\
\text { sustainable future. } \\
\text { Processes of planning, } \\
\text { policy-making, and action } \\
\text { for sustainability by } \\
\text { governments, businesses, } \\
\text { non-governmental } \\
\text { organizations, and the public. }\end{array}$ & $\begin{array}{c}\text { Frame of appropriate } \\
\text { questions to guide relevant } \\
\text { study and research. } \\
\text { Define such fundamental } \\
\text { concepts as environment, } \\
\text { community, development, } \\
\text { and technology, and apply } \\
\text { definitions to local, national, } \\
\text { and global experience. } \\
\text { Assess the nature of different } \\
\text { biases and evaluate different } \\
\text { points of view. } \\
\text { Develop hypotheses based } \\
\text { on balanced information, } \\
\text { critical analysis, and careful } \\
\text { synthesis, and test them } \\
\text { against new information } \\
\text { and personal experience and } \\
\text { beliefs. } \\
\text { Develop cooperative } \\
\text { strategies for appropriate } \\
\text { action to change present } \\
\text { relationships between } \\
\text { environmental preservation } \\
\text { and economic development. }\end{array}$ & $\begin{array}{l}\text { An appreciation of the dependence } \\
\text { of human life on the resources of a } \\
\text { finite planet. } \\
\text { An appreciation of the role of } \\
\text { human ingenuity and individual } \\
\text { creativity in ensuring survival } \\
\text { and the search for appropriate } \\
\text { and sustainable progress and an } \\
\text { appreciation of the power of human } \\
\text { beings to modify the environment } \\
\text { A respect for other cultures and } \\
\text { recognition of the interdependence } \\
\text { of the human community, and } \\
\text { a concern for disparities and } \\
\text { injustices, a commitment to } \\
\text { human rights, and to the peaceful } \\
\text { resolution of conflict. } \\
\text { An appreciation of the challenges } \\
\text { faced by the human community } \\
\text { in defining the processes } \\
\text { needed for sustainability and in } \\
\text { implementing the changes needed, } \\
\text { but also a personal acceptance } \\
\text { of a sustainable lifestyle and a } \\
\text { commitment to participate in } \\
\text { change. } \\
\text { An appreciation of the importance } \\
\text { and worth of individual } \\
\text { responsibility and action. }\end{array}$ & $\begin{array}{l}\text { Acquire skills to assess and } \\
\text { apply complex management } \\
\text { concepts in order to solve } \\
\text { environmental challenges. } \\
\text { Gain knowledge in } \\
\text { environmental sciences and } \\
\text { their practical application. } \\
\text { Combine a theoretical } \\
\text { orientation with practical } \\
\text { project work. } \\
\text { Understanding of the social } \\
\text { and political implications of } \\
\text { planning and managing within } \\
\text { the environmental field. } \\
\text { Understanding the } \\
\text { relationships between } \\
\text { companies and stakeholders, } \\
\text { the environmental challenges } \\
\text { facing businesses operating } \\
\text { on international markets, and } \\
\text { an introduction to various } \\
\text { types of environmental } \\
\text { regulations. }\end{array}$ \\
\hline
\end{tabular}

of positive beliefs, attitudes, and values concerning the environment as a basis for assuming a wise stewardship role toward planet Earth (Table 1).

It should surely be concluded that "environmental education is a process that allows individuals to explore environmental issues, engage in problem-solving, and take action to improve the environment. As a result, individuals develop a deeper understanding of environmental issues and have the skills to make informed and responsible decisions" [21].

In adition, it is evident that climate change is no more a distant problem, and that humanity is faced with experiencing changes in climatic variables: rising temperatures, variable rainfall, and frequent droughts, hurricanes, and typhoons [22-24]. Bearing in mind that climate change is certainly among the most dangerous environmental problems, it has to be emphasized in environmental education [25]. "This is certainly important in the field of climate change, where an educated citizenry is required to make wise decisions regarding policies and practices aimed at reducing greenhouse gas emissions and the human impact on the Earth's resources" [26].

The specific environmental education that considers climate change aims to help young people understand and address the impact of climate change, and encourage changes in their attitudes and behavior for necessary adaptation to climate change-related trends [14]. These are the reasons why "higher education, in particular, has an important role to play in educating students about climate change" [26].

\section{Materials and Methods}

For our research we chose ungraduate students of the University of Belgrade in the Faculty of Organizational Sciences who were enrolled in the elective course Design for Environment in the winter semester of 2016/2017, and who participated in the climate change-oriented project in cooperation with the environmental student organization (EkoFON) at the Belgrade Science Festival. The Belgrade Science Festival, one of the top five science festivals in Europe, represents the most popular and most important annual scientific event. The last five Science Festivals recorded 30,000 visitors and hosted 45 scientific and educational institutions with more than 550 scientific demonstrators [27].

As the mentioned course, a framework and a curriculum for good environmental higher education are developed on a wide scale of scientific and practical knowledge of the environment and environmental science as a good benchmark for the adequate improvement of 
students' knowledge, as well as the promotion of higherorder thinking skills in a cooperative context for learning and evaluation $[20,28]$.

Considering the need for developing new approaches for improving climate change awareness and knowledge [29] and the fact that the chosen course has a section concerning climate change, we conducted a pilot study on project-based learning as a relevant learning model for the $21^{\text {st }}$ century [30], and an approach "that has a positive effect on increasing students' environmental knowledge levels" [31], bearing in mind that this teaching method enables students to gain knowledge and skills by working on an original project that addresses a global issue, in this case climate change. In this way, in addition to their environmental and climate change knowledge, students got familiar with: promoting environmental protection and environmental science in its broadest sense, as well as management and project management.

Students who participated in this project got direct experience that provided them with both theoretical and practical environmental and climate change knowledge needed to increase festival visitors' understanding of climate change and climate change consequences, presented through the polar caps melting and the extinction of polar bears [32]. (Polar bears were chosen because they are very important for addressing climate change as they depend on sea ice for survival and serve as an essential indicator species; the preservation of the polar bear means that humanity needs to restore the lower levels of carbon dioxide in the atmosphere, prevent the melting of the Arctic ice, create reforestation of the Amazon, and reduce greenhouse gas emissions.)

The aim of our research was to evaluate students' learning outcomes as a result of such practical, projectbased learning on climate change, as well as to promote this kind of higher environmental education.

\section{Instruments}

After the Science Festival in Belgrade that took place in December 2016, the authors of the paper conducted the research. For the purpose of this study, a questionnaire was used on a sample of students aged 22 to 24 years. We designed a questionnaire to assess improvement in environmental and climate change knowledge, and to gain results on the main research questions of our study.

The questionnaire consisted of 21 questions. The first four questions were general. From question 5 to question 11, participants were asked to give their responses on their views and impressions on the Belgrade Science Festival. From question 12 to question 21, the participants were asked to express their opinions about: preparations for the climate change project, participation in the project at the Science Festival, the motivation for acquiring more specific environmental knowledge, and a possible change of environmental behavior as well as further engaging in environmental actions. The Likert scale from 1 to 5 has been used (1: absolutely no, 2: I don't agree, 3: I don't know, 4: I agree, and 5: absolutely yes). These questions fall into the category of the most significant ones because they directly refer to the main goals of our research and research questions:

- RQ1: Is a method of learning that involves participation in the project of an interactive exhibit at the Belgrade Science Festival more interesting than the classic method of studying for students?

- RQ2: Does this method result in higher motivation for learning and gaining knowledge?

- RQ3: After participation in this project are students more motivated to change their environmental behavior?

\section{Data Analysis}

An analysis of the results was carried out using the SPSS 24 software package. Descriptive statistics have been used in order to analyze the characteristics of the sample. The Mann-Whitney U test was conducted in order to compare two independent groups in regards to an observed scale variable. The $p$ value is used to indicate if the differences between two particular groups that were in this research are statistically significant (where $p<0.05$ is considered statistically significant at the $95 \%$ confidence level).

\section{Results and Discussion}

Our research sample included 45 students (100\%), and out of that number:

- 24 of them $(53.3 \%)$ were female while 21 of them (46.7\%) were male.

- Of the surveyed respondents, 25 of them (55.6\%) completed a four-year high school, and 20 of them (44.4\%) a secondary occupational school.

- 16 respondents $(35.6 \%)$ are from Belgrade, while the other $29(64.4 \%)$ are from different cities of the Republic of Serbia.

After descriptive statistics, Mann-Whitney rank test was used in order to examine differences in answers between two categories:

- Female/male ratio.

- Four-year high school completed/ocupational school completed ratio.

The arithmetic mean of statements by examined categories - gender and students' previous education - is given in Table 2.

When it comes to testing the difference in the responses of female and male students, there are observed differences in responses:

- "This type of work motivated me in environmental change for the better."

- "This type of work has motivated me to continue to participate in environmental actions."

The results by gender pointed out that:

- Female students showed a greater degree of willingness for environmental change for the better (mean rank for females is 26.44 and for males $19.07, p=0.037$ ). 
Table 2 . The arithmetic mean of statements by examined categories - gender and students' previous education.

\begin{tabular}{|c|c|c|c|c|}
\hline \multirow{2}{*}{ Statement } & \multicolumn{4}{|c|}{$\begin{array}{l}\text { Arithmetic mean } \\
\left(\mathrm{t}_{\mathrm{n}}\right)\end{array}$} \\
\hline & Female & Male & $\begin{array}{l}\text { Four-year high } \\
\text { school }\end{array}$ & $\begin{array}{c}\text { Secondary } \\
\text { occupational school }\end{array}$ \\
\hline $\begin{array}{l}\text { Preparations for the festival have helped me to better assimilate } \\
\text { knowledge on climate change }\end{array}$ & 4.63 & 4.71 & 4.64 & 4.70 \\
\hline $\begin{array}{l}\text { Participation in the festival has helped me to better assimilate } \\
\text { knowledge on climate change }\end{array}$ & 4.58 & 4.62 & 4.52 & 4.70 \\
\hline Preparations for the festival were interesting & 4.17 & 4.14 & 4.24 & 4.05 \\
\hline Participation in the festival was interesting & 4.58 & 4.67 & 4.52 & 4.75 \\
\hline $\begin{array}{c}\text { This type of work has motivated me to learn more about climate } \\
\text { change }\end{array}$ & 4.63 & 4.38 & 4.48 & 4.55 \\
\hline $\begin{array}{c}\text { This type of work has motivated me to learn more about ecology } \\
\text { and environmental protection }\end{array}$ & 4.58 & 4.71 & 4.68 & 4.60 \\
\hline $\begin{array}{l}\text { This type of work has motivated me to change my environmental } \\
\text { behavior for the better }\end{array}$ & 4.54 & 4.14 & 4.32 & 4.40 \\
\hline $\begin{array}{c}\text { This type of work has motivated me to continue to participate in } \\
\text { environmental actions }\end{array}$ & 4.58 & 4.10 & 4.60 & 4.05 \\
\hline $\begin{array}{l}\text { Other subjects should incorporate participating in similar } \\
\text { projects }\end{array}$ & 4.46 & 4.38 & 4.32 & 4.55 \\
\hline I would participate again in this or similar activities & 4.88 & 4.86 & 4.92 & 4.80 \\
\hline
\end{tabular}

- Females showed a greater willingness to participate in future environmental actions (mean rank for females is 26.42 and for males 19.10, $p=0.040)$.

Further on, the average score for the statement: "This type of work motivated me in environmental change for the better" for female students is 4.54 and for male students is 4.14 , which shows greater difference between female and male students. Also, there is a greater difference in the statement: "This type of work has motivated me to continue to participate in environmental actions" where the average score for female students is 4.58 , while for male students it is 4.09 . The arithmetic mean by gender for these two statements and absolute arithmetic mean difference are given in Table 3 and Fig. 1.

These results could be explained by previous research that showed [30]:

Table 3. The arithmetic mean of statements by gender and absolute arithmetic mean difference.

\begin{tabular}{|c|c|c|c|}
\hline \multirow{2}{*}{ Statement } & \multicolumn{2}{|c|}{$\begin{array}{c}\text { Arithmetic mean } \\
\left(\mathrm{t}_{\mathrm{n}}\right)\end{array}$} & $\begin{array}{c}\text { Absolute } \\
\text { arithmetic } \\
\text { mean } \\
\text { difference }\end{array}$ \\
\cline { 2 - 4 } & Female & Male & \\
\hline $\begin{array}{c}\text { This type of work has } \\
\text { motivated me to change } \\
\text { my environmental } \\
\text { behavior for the better }\end{array}$ & 4.54 & 4.14 & 0.40 \\
\hline $\begin{array}{c}\text { This type of work } \\
\text { has motivated me to } \\
\text { continue to participate in } \\
\text { environmental actions }\end{array}$ & 4.58 & 4.09 & 0.49 \\
\hline
\end{tabular}

- Females have more positive attitudes toward nature and the environment than males.

- Females are more likely than males to show a motivation to behave responsibly when it comes to the protection of nature and the environment.

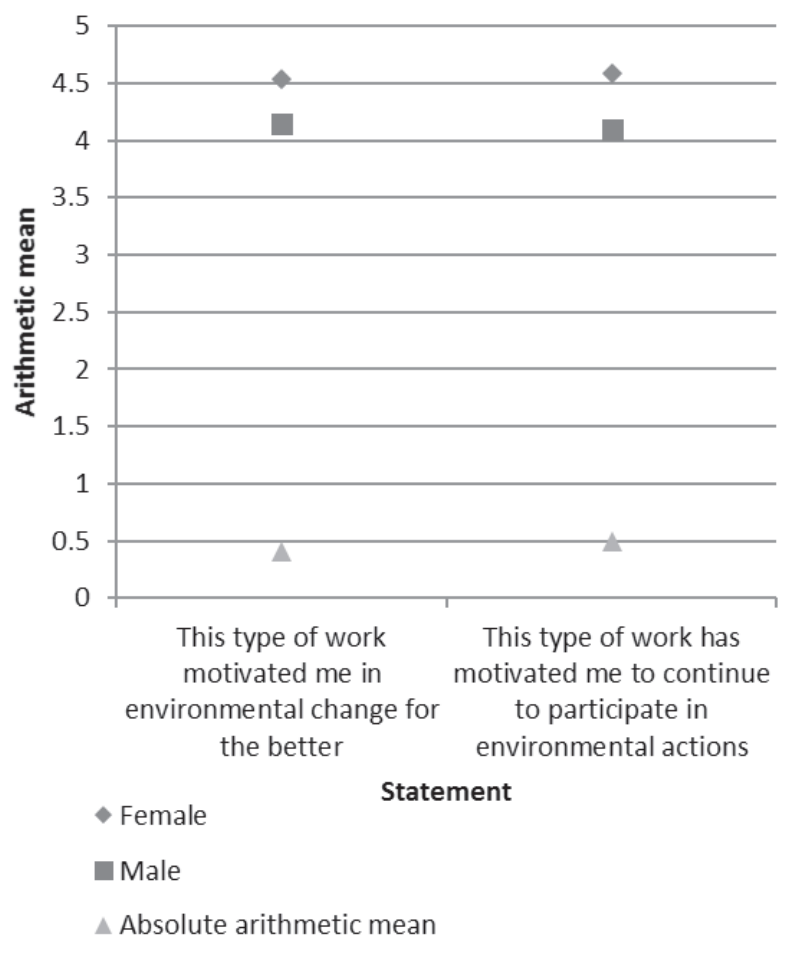

Fig. 1. The arithmetic mean of statements by gender and absolute arithmetic mean difference. 
- Females showed more hope than males of making the world a better place by changing their environmental behaviors.

It must be noted that these results are of great interest, having in mind the importance of the linkages between environmental protection and security and gender roles as well as necessary involvement of females in environmental education [33]. Also, engaging females in environmental protection helps societies to develop "the sense of responsibility needed to maintain a good balance between humans and the earth's resources" [34].

In addition, in our research we examined the differences in the responses of students who have completed a fouryear high school and university students who have completed a secondary occupational school. A statistically significant difference was found in the assessment of only one statement: "This type of work has motivated me to continue to participate in environmental actions." Results show that students who have completed a four-year high school are more willing to participate in environmental actions than the students who have completed an occupational school (mean rank for four-year high school students is 26.4, mean rank for occupational school students is $18.75, p=0.033$ ). The arithmetic mean of statements by students' previous education and absolute arithmetic mean difference are given in Fig. 2.

These results can be explained on the basis of the curriculum in biology and sociology as subjects in four-year high schools where they taught the basics of ecology and environmental problems [35] as opposed to occupational schools that do not have these subjects.

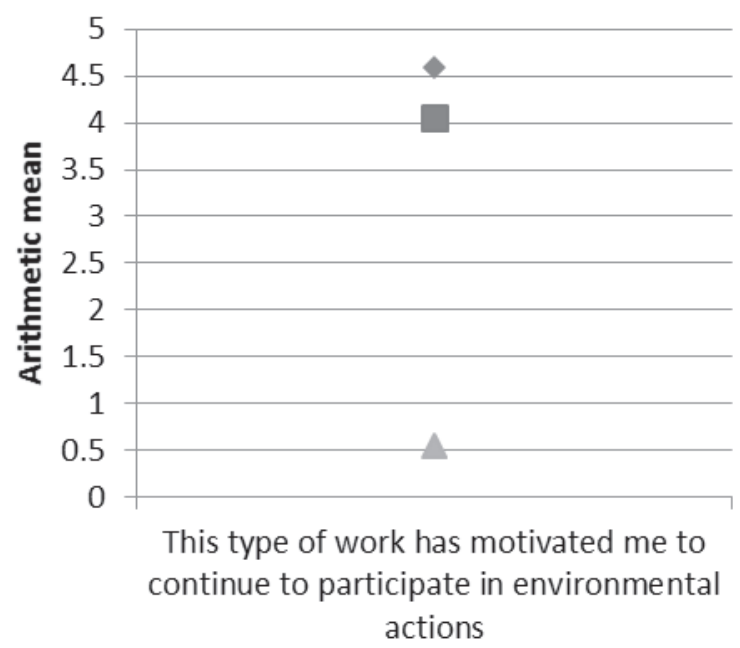

Statement

$\checkmark 4$ year high school

Secondary occupational school

\section{Absolute arithmetic mean}

Fig. 2. The arithmetic mean of statements by students' previous education and absolute arithmetic mean difference.
On the one hand, this is associated with the results of previous studies that have shown that when it comes to environmental education in the Republic of Serbia, data about educational curriculum and programs has shown an evident lack of formal and permanent environmental education at all levels of formal education [17, 28, 36-38]. On the other hand, the results of our research show the necessity of not only implementing formal environmental education, but of the development of such an education, which includes the necessary environmental activities with the aim of promoting and protecting the environment in the long run. Or environmental education must include "participation in activities that lead to the resolution of environmental challenges" [30].

What should be pointed out as the biggest success of the project is the fact that 40 of the surveyed students $(88.9 \%)$ answered affirmatively to the question whether they would take part in the Belgrade Science Festival again, and that the opinions of students on project-based learning organized in this way are the following:

- A good way to gain knowledge in the field of ecology and environmental protection.

- An interesting and pleasant experience.

- Gained new knowledge and experiences.

- Fun, interesting, and educational.

- The Science Festival and this project encouraged me to think more about the subject of climate change and change my behavior for the better.

Further on, in order to evaluate student satisfaction with their preparation and participation in the project as well as their assessment to the statements relating to their motivation to learn more about environmental issues treated by the climate change project, and then consequently change their environmental behavior and continue with environmental activities, the students gave marks on a scale of 1 to 5 based on the truthfulness of the statement, and we calculated the arithmetic mean. The ranked results based on the assessment given by students to our 10 statements are shown in Table 4.

From the calculated results the following can be concluded:

- The highest average rating of 4.87 received the statement: "I would participate again in this or similar activities" (rank 1), which says that the students liked this active method.

- Next, the average score of 4.67 for the statement: "Preparations for the Science Festival have helped me to better assimilate knowledge on climate change" (rank 2), which shows that project-based learning gives better results in gaining knowledge and teaching the curriculum.

- Statement: "This type of work has motivated me to learn more in ecology and environmental protection" also received a high rating of 4.64 .

The results from the questionnaire showed students' answers on three main research questions of our study. Based on the students' marks given to the specified statement, we concluded the following: 
Table 4. Ranked assessment of statements by students.

\begin{tabular}{|c|c|c|}
\hline Statement & $\begin{array}{c}\text { Arithmetic mean } \\
\left(\mathrm{t}_{\mathrm{n}}\right)\end{array}$ & Rank \\
\hline $\begin{array}{c}\text { I would participate again in } \\
\text { this or similar activities }\end{array}$ & 4.87 & 1 \\
\hline $\begin{array}{c}\text { Preparations for the festival } \\
\text { have helped me to better } \\
\text { assimilate knowledge on } \\
\text { climate change }\end{array}$ & 4.67 & 2 \\
\hline $\begin{array}{c}\text { This type of work has } \\
\text { motivated me to learn } \\
\text { more about ecology and } \\
\text { environmental protection }\end{array}$ & 4.64 & 3 \\
\hline $\begin{array}{c}\text { Participation in the festival } \\
\text { was interesting }\end{array}$ & 4.62 & 4 \\
\hline $\begin{array}{c}\text { Participation in the festival } \\
\text { has helped me to better } \\
\text { assimilate knowledge on } \\
\text { climate change }\end{array}$ & 4.60 & 5 \\
\hline $\begin{array}{c}\text { This type of work has } \\
\text { motivated me to learn more } \\
\text { about climate change }\end{array}$ & 4.51 & 6 \\
\hline $\begin{array}{c}\text { Other subjects should } \\
\text { incorporate participating in } \\
\text { similar projects }\end{array}$ & 4.42 & 7 \\
\hline $\begin{array}{c}\text { This type of work has } \\
\text { motivated me to change my } \\
\text { environmental behavior for } \\
\text { the better }\end{array}$ & 4.36 & 8 \\
\hline $\begin{array}{c}\text { This type of work has } \\
\text { motivated me to continue to } \\
\text { participate in environmental }\end{array}$ & & 6 \\
\hline $\begin{array}{c}\text { Preparations for the festival } \\
\text { were }\end{array}$ & & \\
\hline
\end{tabular}

- Students assessed with a high mark (4.62) the presented way of learning that involves the participation in climate change-oriented project at the Belgrade Science Festival in comparison with the classic method of studying. This result gave us excellent feedback on the first research question.

- When it comes to assessing the method of projectbased learning with consequent higher motivation for learning and gaining environmental and climate change knowledge, the average mark is excellent, too (4.61).

- Finally, the last research question related to the students' motivation to change their environmental behavior got the lowest, but still a very good mark at 4.36 .

The results of student answers on three main research questions of our study are given in Table 5.

In addition, we analyzed individual arithmetic mean of assessment of questionnaire statements by students, as well as its frequency. Gained results showed that a large number of students - $26(57.8 \%)$ - gave excellent average marks equal to or greater than $4.50,4$ of them (8.9\%) gave mark 4.50 , and the rest of the students gave a mark greater than $4.50(48.9 \%)$. The interesting fact is that the most common individual average marks were 4.40 and 4.60 $(20 \%)$. Arithmetic mean of statements and frequency by students are given in Table 6.

Aslo, on the question "Would you recommend this climate change-oriented project activity to your colleagues?," all students answered positively (100\%). These results strongly supported the main idea of our research - that higher environmental education must be a non-traditional education that relies on relevant modern teaching models such as project-based learning. Only by this kind of education will it be possible to seriously increase students' environmental knowledge level.

Table 5. Answers to main research questions by students.

\begin{tabular}{|c|c|c|}
\hline Main researh question & Statement & $\begin{array}{l}\text { Arithmetic mean } \\
\left(t_{n}\right)\end{array}$ \\
\hline $\begin{array}{l}\text { Is a method of learning that involves participation } \\
\text { in the project of an interactive exhibit at the } \\
\text { Science Festival more interesting than the classic } \\
\text { method of studying for students? }\end{array}$ & Participation in the festival was interesting & 4.62 \\
\hline \multirow{4}{*}{$\begin{array}{l}\text { Does this method result in higher motivation for } \\
\text { learning and gaining knowledge? }\end{array}$} & $\begin{array}{l}\text { Preparations for the festival have helped me to } \\
\text { better assimilate knowledge on climate change }\end{array}$ & \multirow{4}{*}{4.61} \\
\hline & $\begin{array}{l}\text { Participation in the festival has helped me to } \\
\text { better assimilate knowledge on climate change }\end{array}$ & \\
\hline & $\begin{array}{l}\text { This type of work has motivated me to learn } \\
\text { more about climate change }\end{array}$ & \\
\hline & $\begin{array}{c}\text { This type of work has motivated me to learn } \\
\text { more about ecology and environmental } \\
\text { protection }\end{array}$ & \\
\hline \multirow{2}{*}{$\begin{array}{l}\text { After participation in this project are students more } \\
\text { motivated to change their environmental behavior? }\end{array}$} & $\begin{array}{l}\text { This type of work has motivated me to change } \\
\text { my environmental behavior for the better }\end{array}$ & \multirow{2}{*}{4.36} \\
\hline & $\begin{array}{l}\text { This type of work has motivated me to continue } \\
\text { to participate in environmental actions }\end{array}$ & \\
\hline
\end{tabular}


Table 6. Arithmetic mean of statements and frequency by students.

\begin{tabular}{|c|c|c|}
\hline Arithmetic mean $\left(\mathrm{t}_{\mathrm{n}}\right)$ by student & Frequency & $\%$ \\
\hline 3.80 & 1 & 2.2 \\
\hline 3.90 & 1 & 2.2 \\
\hline 4.00 & 2 & 4.4 \\
\hline 4.20 & 1 & 2.2 \\
\hline 4.30 & 5 & 11.1 \\
\hline 4.40 & 9 & 20 \\
\hline 4.50 & 4 & 8.9 \\
\hline 4.60 & 9 & 20 \\
\hline 4.70 & 5 & 11.1 \\
\hline 4.80 & 1 & 2.2 \\
\hline 4.90 & 3 & 6.7 \\
\hline 5.00 & 4 & 8.9 \\
\hline Total & 45 & 100 \\
\hline
\end{tabular}

\section{Conclusions}

The obtained results from our research pointed out that:

Students who have completed a four-year high school are more likely to participate in environmental actions.

Project-based learning such as this teaching method resulted in students showing greater motivation to learn more, better accept knowledge, and being willing to participate again in similar activities.

Female students showed a greater degree of willingness for environmental improvement and participation in environmental actions.

Gender roles are significant predictors of perception of nature, environmental problems, and environmental behavior.

Our preliminary results and data showed great progress and encouraged us to continue exploring this area, considering the fact that this is a pilot study, and the initial stage of a future larger project of monitoring students' scientific and practical environmental and climate change literacy in undergraduates. The study results definitely demonstrated a positive result on our research questions related to this kind of specific project-based learning in higher environmental education. Also, this specific research shows us that this kind of teaching method is without a doubt a tool of student interest, because it keeps students significantly motivated and improved their knowledge on environment and climate change.

To sum up, our results confirmed earlier studies [29] that indicated the importance of practical higher environmental education such is the proposed education based on a climate change-oriented project as an excellent way to make students more involved in the core of climate change as an inherently global issue. In addition, this kind of higher environmental education adequately answered the high challenge for universities related to the integration of necessary different perspectives and concepts that radically innovate methods of education [39-41].

In addition, regarding the results of our research, we can conclude that using a project like this in higher environmental education increases the learning productivity of students and improves their interest in environmental issues, with consequent enhancement of student awareness of necessity for taking environmental action and changing environmental behavior patterns.

\section{Acknowledgements}

The authors would like to thank the student environmental organization EkoFON, the Faculty of Organizational Sciences, and the Belgrade Science Festival in the Republic of Serbia for their cooperation in organizing the project used in this study.

\section{References}

1. BONNETT M. Environmental education and the issue of nature. J. Curriculum Stud., 39 (6), 707, 2007.

2. MERT M. Determination of consciousness level of high school students on the environmental training and solid wastes topics. Hacettepe University: Ankara, Tureky, 2006.

3. ROBERT L., FLOOD E., CARSON R. Dealing with complexity. Plenum Publishing: New York, NY, United States, 1993.

4. PETROVIC N. Ekološki menadžment, $3^{\text {rd }}$ ed.; Fakultet organizacionih nauka: Beograd, Srbija, 2016 [In Serbian].

5. SYMTH J. Environment and education: A view of a changing scene. Environ. Educ. Res., 12 (4), 247, 2004.

6. YOUNG J.L.M. All education is environmental education, Doctoral dissertation; Queen's University: Ontario, Canada, 2009.

7. ESD Sourcebook. Learning \& Training Tools, No. 4. Available online: http://unesdoc. unesco.org/ images/0021/002163/216383e.pdf (accessed on 27.12.2016.).

8. The Stockholm Declaration (Declaration of the United Nations Conference on the Human Environment). Available online: http://www.unep.org/Documents.multilingual/ Default.asp?DocumentID=97\&ArticleID=1503 (accessed on 07.01.2017.).

9. The Belgrade Charter. Available online: http://unesdoc. unesco.org/images/0001/000177/017772eb.pdf (accessed on 27.12.2016.)

10. The Tbilisi Declaration. Available online: http://www.gdrc. org/uem/ee/tbilisi.html (accessed on 15.01.2017.).

11. HINES J.M., HUNGERFORD H.R., TOMERA A.N. Analysis and synthesis of research on responsible environmental behavior: A meta-analysis. J. Environ. Educ., 18, 1-8, 1986/87.

12. HUNGERFORD H.R., VOLK T.L. Changing learner behavior through environmental education. . J. Environ. Educ., 21 (3), 8, 1990.

13. New UN Report Details Link between Climate Change and Human Rights. Available online: http://www.unep.org/ 
NewsCentre/default.aspx? DocumentID=26856\&Article $\mathrm{ID}=35630$ (19.01.2017.).

14. Climate Change Education. Available online: http:// en.unesco.org/themes/education-sustainable-development/ cce (accessed on 20.01.2017.).

15. NAMIESNIK J. Protection of the Environment-the Most Important Challange for the Educational System. Pol. J. Environ. Stud., 8, 293, 1999.

16. SAKA A., SAHINTURK A. Attitudes of prospective forest engineers and primary school teachers toward a sustainable environment. Pol. J. Environ. Stud., 22 (5), 1553, 2013.

17. PETROVIC N. Development of higher environmental education program. Management - Časopis za teoriju i praksu menadžmenta, 15 (56), 35, 2010.

18. PETROVIC N., ISLJAMOVIC S., JEREMIC, V. A new concept for measuring achievement levels in higher environmental education. Energy Education Science and Technology Part B - Social and Educational Studies, 5 (2), 809, 2013.

19. PETROVIC N., JEREMIC V., PETROVIC D., CIROVIC M. Modeling the Use of Facebook in Environmental Higher Education. In The Social Classroom: Integrating Social Network Use in Education, G. Mallia, Ed., Information Science Reference: Hershey, PA, United States of America, 100, 2014.

20. North American Association for Environmental Education - NAAEE. Environmental Education Materials: Guidelines for Excellence. NAAEE: Rock Spring, GA, United States of America, 1996.

21. What is Environmental Education? Available online: https:// www.epa.gov/education/what-environmental-education (accessed on 22.01.2017.).

22. AUFFHAMMER M., RAMANATHAN V., VINCENT J.R. Climate change, the monsoon, and rice yield in India. Clim. Change, 111 (2), 411, 2011.

23. LOBELL D.B., SIBLEY A., IVAN ORTIZ-MONASTERIO J. Extreme heat effects on wheat senescence in India. Nat. Clim. Change, 2 (3), 186, 2012.

24. TRIPATHI A., MISHRA A.K. Knowledge and passive adaptation to climate change: An example from Indian farmers. Clim. Risk Manag., in press, 2016.

25. ARSLAN S. The influence of environment education on critical thinking and environmental attitude. Procedia Soc. Behav. Sci., 55, 902, 2012.

26. REES W.E. Impeding sustainability? The ecological footprint of higher education. Plann. Higher Educ., 31, 88, 2003.

27. About Science Festival. Available online: http:// festivalnauke.org/In-English2 (accessed on 25.01.2017.).
28. BAKER E., TRYGG B., OTTO P., TUDOR M., FERGUSON L. Project-based Learning Model, Relevant Learning for the $21^{\text {st }}$ Century. Pacific Education Institute: Columbia, United States, 2011.

29. CORDERO E.C., MARIE TODD, A., ABELlERA, D. Climate change education and the ecological footprint. B. Am. Meteorol. Soc., 89 (6), 865, 2008.

30. EISLER A. D., EISLER H., YOSHIDA M. Perception of human ecology: cross-cultural and gender comparisons. J. Environ. Psychol., 23 (1), 891, 2003.

31. ARMAGAN F.O., KOKSAL E.A. Factors effecting students' performances on an environment achievement test. Procedia Soc. Behav. Sci., 9, 1585, 2010.

32. Spasimo medu da bi sve bilo u redu. Available online: http:// festivalnauke.org/Program/Beogradski-sajam/Spasimomedu-da-bi-sve-bilo-u-redu (accessed on 29.01.2017.) [In Serbian].

33. Organization for Security and Co-operation in Europe. Gender and Environment: A guide to the integration of gender aspects in the OSCE's environmental projects. 2009.

34. Importance of women's participation in protecting environment stressed, as women's commission holds second expert panel discussion. Available online: http://www. un.org/press/en/2002/WOM1325.doc.htm (accessed on 01.02.2017.).

35. Programi gimnazija. Available online: http://tesla.pmf.ni.ac. rs/people/nesiclj/predavanja/metodika/programi\%20skola/ plan\%20i\%20program\%20za\%20gimnaziju.pdf (accessed on 02.02.2017.) [In Serbian].

36. KLEMENOVIC J. Činioci ekološkog vaspitanja i obrazovanja. Pedagoška stvarnost, 50 (5-6), 366, 2004 [In Serbian].

37. PAVLOVIC V., Ed. Univerzitet i održivi razvoj. Fakultet političkih nauka: Beograd, Srbija, 2011 [In Serbian].

38. TRUMIC M., PETROVIC N., RADOJCIC Z. Ekološka svest u formalnom osnovnom obrazovanju Republike Srbije. XXXVII Symposium on Operation Research, SYM-OP-IS 2009, Ivanjica, Srbija, 3, 2009 [In Serbian].

39. LOZANO R. Incorporation and institutionalization of SD into universities: breaking through barriers to change. J. Clean. Prod., 14 (9), 787, 2006.

40. SVANSTRÖM M., LOZANO-GARZIA F.J., ROWE D., 2008. Learning outcomes for sustainable development in higher education. Int. J. Sustain. High. Educ., 9, 339, 2008.

41. ZSÓKA Á., SZERÉNYI Z.M., SZÉCHY, A., KOCSIS, T. Greening due to environmental education? Environmental knowledge, attitudes, consumer behavior and everyday pro-environmental activities of Hungarian high school and university students. J. Clean. Prod., 48, 126, 2013. 